\title{
Special Issue on the Integration between Asia and Europe
}

\author{
Guest Editors \\ K.C. Fung, Alicia Garcia-Herrero, Andre Sapir \\ and \\ Jong-Eun Lee
}

This special issue aims to shed light on the multi dimensional aspects of economic integration among the world's vast, distinct, and two adjacent regions on the continental scale: that is, Asia and Europe. Distinguished researchers weave various strands of economic integration between Asia and Europe that are sometimes seemingly intangible but spectacularly evolving.

Touching upon a number of facts related to their integration, China is now the 2nd largest trading partner for the European Union (EU), behind only the United States, while the EU is China's largest trading partner. The Association of Southeast Asian Nations (ASEAN) as a whole represents the EU's 3rd largest trading partner, while the EU is ASEAN's 2nd largest trading partner after China. In terms of investments, Japan is a major investor in the EU while European companies are the largest investors in ASEAN countries and South Korea. Besides the EU-Korea Free Trade Agreement, the EU's first trade deal with an Asian country, entered into force in July 2011. Since then, the EU has launched FTA negotiations with several ASEAN countries (Malaysia, Thailand and Vietnam) and with Japan.

The paper by Mitsuyo Ando and Fukunari Kimura on "Production Linkage of Asia and Europe via Central and Eastern Europe" uncovers interesting geographical pictures in production sharing over the period of 1995 2010, i.e., the EU enlargements play a key role in production sharing in Asia and Europe. The forerunners in production sharing were Hungary and the Czech Republic in 1995, with Slovakia, Poland, and Romania joining subsequently in 2010. The EU enlargements connect East Asia and the EU through Central and Eastern Europe and have become tighter over time, facilitated by Korean and Japanese multinationals. This is 
also a theme related to the seventh paper by Aminian, Fung, Garcia-Herrero, Iizaka, and $\mathrm{Ng}$, who examine how French, German, or Japanese foreign direct investments facilitate production networks.

The article on "Exchange Rate Devaluation and Reshuffling of Global Jobs" by Luca Macedoni and Fabio Sdogati is original in the sense that few papers consider exchange rates and consequently changing production structures even if this is a hot issue amidst the chronic global crisis. The authors start with a 3-country theoretical model of production fragmentation in a Ricardian continuum of goods framework. They examine the effects of exchange rate devaluation by a high-productivity country relative to the currency of a low-productivity country, and find that production fragments move from the low-productivity country to the moderately productive economy whereas the specialization of the high-productivity country remains unchanged. The extension of the model to an $\mathrm{N}$-country case makes the central message intact: With a global production network, a devaluation of the currency in an importing country relative to the currency of an exporting country transfers the production fragments from the latter to the former only if the two countries produce fragments that are close in the continuum. Empirical evidence using the World Input-Output Table by and large supports the theoretical hypothesis.

Shekhar Aiyar and Sonali Jain-Chandra provide a view on the global banking perspective between Asia and Europe through "Asia and Europe are Different?: Credit Response to Global Bank Deleveraging." During the global financial crisis, the foreign claims of euro areas and U.K. banks in Asia fell by $37 \%$ and $21 \%$ of outstanding claims, respectively. A $1 \%$ decline in foreign claims by European banks was associated with a decline in domestic credit by about $0.5 \sim 0.7 \%$ in the broad sample, but a decline of only around $0.3 \sim 0.4 \%$ for Asian economies. Different results for Asia were due to the fact that the policy responses by various Asian economies were vigorous as seen in liquidity guarantees, negotiating Federal Reserve swap lines and expanding deposit insurance and relatively healthy local banking systems in Asia. The banking systems in advanced Americas and advanced Europe were much more leveraged than their counterparts in advanced Asia. The link of European banks with Asia is not only crucial to understand the past, but it can be of use to gain insights to future impacts on Asia.

A policy-oriented article by Patrick Messerlin on “The EU's Strategy for Trans-Pacific Partnership" shows the various aspects on Trans-Pacific Partnership (TPP) agreement such as a potential inclusion of Japan and exclusion of Mainland China from the EU perspective. The potential success of the TPP can be a serious blow to the European economies. First, a major source of trade diversion stems from Japan if Japan joins in the TPP. Second, TPP includes five of the most important world exporters of agricultural products, and thus poses a threat to European exporters of agricultural products. Third, risks of discriminatory impacts towards the EU in services and international investment are expected. For the EU strategy, the author 
claims that doing nothing is even more costly as the economic weight of the EU is expected to decline, while the economic weight of the Asia-Pacific region will rise. The constructive option is to actively pursue bilateral free trade agreements with Asian-Pacific economies of which the major candidates would be Japan and Taiwan. Unlike the TPP that excludes Mainland China and that is pushed by the United States, the EU can more easily approach Taiwan without seriously offending Mainland China.

Hylke Vandenbussche, Francesco Di Comite, Laura Rovegno, and Christian Viegelahn provided this special issue with the paper "Moving Up the Quality Ladder? EU-China Dynamics in Clothing," in which the authors compare Chinese and European exports that substantially overlap in the clothing sector since the end of the Multi-Fiber Arrangement in 2005. The higher prices of the EU exports and higher quantities for Chinese exports suggest that the higher prices of EU clothing exports may not reflect a higher quality based on a monopolistic competition model. Also, the core exports of the EU clothing remain stable whereas Chinese export varieties change over time. This paper captures the dynamic features of China as the world's manufacturing economy from the European perspective and predicts fiercer competition European firms would face in the world market.

Aminian, Fung, Garcia-Herrero, Iizaka, and Ng study "French, German and Japanese FDI on Intra-East Asian Trade." Through the lens of intra-East Asian trade in parts, components, and capital goods, the authors explain the historical aspects of production networks, role of small and medium-sized firms, and Foreign Direct Investment, giving a panoramic view of globalization in Asia and Europe. Foreign direct investment from Germany, France, and Japan in Asia all contribute to more intra-Asian trade in parts, components, and capital goods. Japanese foreign direct investment stands out as a stronger effect on the intra-Asian trade, particularly in the capital goods trade.

In "French Firms Penetrating Asian Markets: Role of Export Spillovers" by Florian Mayneris and Sandra Poncet, the authors examine whether the presence of other French exporting firms can help in the exporting of French firms to penetrate Asian markets. Using data from the French Customs, at the firm -, product -, and destination - levels for the period of 1998 2003, a conditional logit estimation finds that the entry year to an export market is positively affected by proximity to other exporters in France the year before; i.e., export spillovers are especially beneficial to small and less productive French firms that are eager to penetrate Asian markets with low GDP per capita and tougher import administrative procedures. Export spillovers are thus heterogeneous at the firm level, suggesting the necessity for an export policy with greater delicacy between Asia and Europe. 